\title{
What Determines the Social Efficiency of Islamic Banking Investment Portfolio?
}

\author{
Rukhsana Kalim ${ }^{1 *}$, Noman Arshed ${ }^{2}$ \\ ${ }^{1}$ Dean, Institute of Islamic Banking, University of Management and Technology (UMT), Lahore, Pakistan \\ ${ }^{2}$ Lecturer in the Department of Economics, School of Business and Economics, UMT, Lahore, Pakistan
}

\section{Keywords \\ Mushärakah \\ Mudārabah \\ Ijārah \\ Murābahah \\ Panel Stochastic Frontier Model \\ Islamic Banking \\ Efficiency}

Received: 01 August 2017

Accepted: 02 May 2018

\begin{abstract}
While operating in competition with conventional banks, Islamic banks need to push up the returns to depositors so that they could attract funds. If an Islamic bank optimizes its investment portfolio to maximize deposit returns, it might have increasing access to the supply of deposit funds. Unlike other studies, which consider return to deposit as a cost, this study considers it as means to public benefit. It has used all 53 known full-fledged Islamic banks operating in Pakistan, Malaysia and MENA countries in a panel stochastic frontier analysis for data between 2001 and 2015 and confirmed that Islamic banks are approximately 26\% optimized. Muda arabah investment presents itself as the best candidate for boosting the efficiency. Also, if the market is favorable in terms of banking profits, market return rate of investment, banking sector development and risks, then efficiency could be increased.
\end{abstract}

KAUJIE Classification: K0, V12, L25, N0

JEL Classification: G21, D61, D63

(C) 2018 JIBM. All rights reserved.

\section{INTRODUCTION}

Like all financial intermediaries, Islamic banks also play a role in terms of indirect financing from the people and businesses having surplus funds to the people and businesses facing shortage of funds. The differentiation of Islamic banks with conventional counterparts is that an Islamic bank uses Sharí ah (Islamic law) compliant means to fulfil all the financial needs. It avoids all the prohibited aspects directly or indirectly mentioned in the sources of Sharī'ah (i.e., Qur'ān, Sunnah, Consensus of Jurists, and deductive analogy) (Khan, 2007). Unlike conventional banks which promise the depositors a fixed (usurious) return from the investment guaranteeing no exposure to risk, Islamic bank provides the depositor with some share in the return based on the profit earned on investment pool, along with the business risk. Islamic bank works on the foundation set by maqāsid al-Sharī'ah where it commits for

\footnotetext{
*Corresponding author: Rukhsana Kalim

†Email: drrukhsana@umt.edu.pk
} 
the provision of justice, brotherhood and social welfare (Dusuki \& Abozaid, 2007). Hence based on this, the objectives of Islamic bank includes profit maximization as well as maximization of social returns, whereby Islamic banks' formulate their investment portfolio that helps in maximizing both bank returns and depositors' returns.

\section{Research Objective and Rationale}

Yusof and Amin (2007) indicated that an Islamic business will strive for public benefit with private benefit, while a study by Maali, Casson, and Napier (2006) using a review of 29 Islamic banks claimed that Islamic banks fall below the expectations in social disclosure. Such kind of analysis motivated this study to explore whether Islamic banks do consider the public benefit in their decision making regarding financial portfolio. Conventional businesses only focus on maximization of equity or assets while maqāsid al-Sharī'ah tends to promote businesses to consider public benefit too. In this perspective, the objectives of the study are manifold. First, this study is to assess how efficient is the Islamic banking and finance in maximising the depositor returns, and what is its distribution across different countries like in Malaysia and Pakistan. Secondly, it examines the role of finance and investment based modes in determining the deposit returns. Lastly, it explores which investment mode can potentially increase the efficiency of the Islamic banks and tests the effect of some indicators like profit of bank, banking sector development, market interest rate (Ergeç \& Arslan, 2013) and credit risk on the efficiency of Islamic banks.

\section{Methodology and Estimation Model}

The study is using the bank based panel data of 53 full-fledged Islamic Banks from 21 countries all across the globe for up to 14 years (2001 - 2015). Based on the availability of Islamic bank's annual reports, the sample is 312 bank-year observations.

The study uses Panel Stochastic Frontier Approach (SFA) as a first model proposed by (Battese \& Coelli, 1992; Kumbhakar \& Lovell, 2000). This approach uses the inputs to construct the grand frontier benchmark of output for the pooled data. Then it evaluates the relative efficiency of each bank for each time period (Mokhtar, Abdullah, \& Al-Habshi, 2006). The advantage of this approach over commonly used efficiency measurement method, Data Envelopment Analysis (DEA) approach is that it differentiates between inefficiency and heteroscedasticity and it can be applied to unbalanced panel data (Bhattacharyya, Lovell, \& Sahay, 1997). While in the second model the determinants of deposit return maximization efficiency are estimated.

First we discuss some theoretical underpinnings concerning deposits, financing and investment portfolios of Islamic banks and the deposits returns.

\section{DEPOSITORS AND ISLAMIC BANK}

There are two major categories of deposit accounts, the current accounts and the saving accounts. In the case of current account, the contract formed between the Islamic bank and the depositor is based on qard al-hasan (interest-free gracious loan) in which depositors only 
have the assurance of principle amount and are not entitled to any return. In case of saving account, the contract formed is called mudärabah (Trust Financing) in which depositor ( $r a b$ $a l-m \bar{a} l$ ) invests with Islamic bank (mudārib (fund manager)). In this setting the exposure to risk makes depositor liable for a profit share, and for the instance of profit, Islamic bank shares profit with the depositor on a pre-agreed ratio, while for the instance of loss, the capital loss is borne by the depositor and time loss is borne by the bank as muda $\mathrm{arib}$. This structure of saving/investment accounts is common across all Islamic banks with few exceptions like UK, whereas per the country regulation the deposit returns must be fixed before time. Islamic banks use the third type of contact named as Tawarruq (reverse of cost plus markup sale (mudārabah)), which creates a disjoint between deposits and investments allowing banks to pay fixed returns (Ahmed, 2011; Hadi \& Hani, 2015; Hussain, Shahmoradi, \& Turk, 2016).

Since deposits are the main source of funds for the bank, consistent supply of deposits is necessary for proper functioning of the asset side. Since in most countries, Islamic banks are operating vis-à-vis conventional banks, this substitutability between the deposit account of Islamic and conventional banks creates a challenge for Islamic banks to attract more depositors. Hence Islamic banks need to find ways to boost deposit returns in order to attract depositors as it is an important determinant (Haron, Azmi, \& Shafie, 2006; Kasri, \& Kassim, 2009; Rachmawati \& Syamsulhakim, 2004). Further, as per the nature of mudārabah as a fiduciary contract, Islamic bank has to use funds responsibly and avoid any undue loss to the depositor (Qur'ān, 8:27).

\section{Islamic Banks and Investments}

Islamic banks, on the asset side, invest the funds generated from deposits in addition to using their own equity. Islamic banks use a wide array of investment options which are designed to fulfil specific requirements of the clients. They have to optimize the use of investment pool in different modes of investments in order to ensure better returns while considering a certain amount of risk. They either finance their clients or invest their funds on the basis of various modes and contracts (Usmani, 2000). Financing is generally through trade and ijārah based modes (murābahah, salam, istiṣna $\bar{a}^{\circ}, i j \bar{a} r a h$ and variants of these modes), while investments are made in stocks, șuku $\bar{k}$ and other securities based on the modes of mushārakah, mudāarabah, ijārah, etc.

In the case of former, i.e., financing, the return in the form of trade profit or ijärah rentals is fixed. In the latter type of investments, Islamic bank becomes a partner to the business by providing capital or expertise. Mushärakah term comes from Arabic nomenclature which means sharing. In terms of business, mushärakah is analogues to a joint venture where both partners can share ownership, capital, expertise, trade or goodwill (Ayub, 2009; Iqbal \& Mirakhor, 2011; Usmani, 2000). Mushärakah can be used both for financing and investment, for medium and long-term financing and project financing, etc. Here the returns are not 
predetermined, in principle ${ }^{1}$, and are dependent on the outcome of the business activity, rate of interest, risk premium and profit sharing ratio (Hassan, 2014). Similarly, mudārabah is a participatory mode variant of mushärakah in which one partner invests money ( $\mathrm{rab} a l-m \bar{a} l$ ) and other partner manages the investment (mudārib) (Ayub, 2009; Iqbal \& Mirakhor, 2011; Usmani, 2000). The returns in such type of investment are based on the performance of the partnership which is variable and is not predictable beforehand. Based on their nature, they tend to have high returns but they entail risk too (Hassan, 2014; Rosly \& Zaini, 2008).

These modes of investment are risky but have a potential for higher returns while modes of trade have predetermined but lower returns benchmarked with interbank offer rate.

Trade and lease based modes for financing are deemed permissible by Sharī'ah for day to day transactions and have been adopted by Islamic banks to finance the customers' needs. Banks earn fixed predetermined rent or profit from these transactions. The predictability in returns and low risk make them favorable to Islamic banks (Usmani, 2000).

Aggarwal and Yousef (2000) state that due to low risk and debt like nature of mode of trade, Islamic banks are more leaned towards them. Hence the overall return to the depositors are determined by the composition of finance and investment portfolio managed by the Islamic bank. There are several studies which explored the effect of financing on bank performance like (Arshed, Riaz, \& Khan, 2017; Garcia \& Guerreiro, 2016) and bank efficiency like (Sadiq, Arshed, \& Ahmad, 2017; Sufian \& Noor, 2009; Yan, 2005). But there is a dearth of studies which tried to connect financing portfolio with depositor returns and its efficiency.

Table 1 shows country wise average of four types of Islamic banking investment using banks available in sample between 2001 and 2015. It indicates that for most of the countries, mode of financing by way of trade and leasing (murābahah and ijārah) have a higher share in total financing and on average mode of trade is $50 \%$ while mode of investment (mushārakah and mudārabah) is only $9 \%$, this hints that banks predominantly are skewed towards less risky financing.

\footnotetext{
${ }^{1}$ Some of its practical versions, however, carry pre-fixed return as the case of "Running mushärakah" that became popular mainly after 2015. RM has been introduced as an alternative to interest based product for running finance. Islamic banks get fixed target rate that is usually equal to the KIBOR with plus or minus. Over and above the target rate, Islamic bank agrees to reduce its profit share as low as 3 or even 4 zeros after decimal $-0.00001 \%$ - and $99.99999 \%$ is given to the client. RM thus becomes a fixed return mode which is covering increasing share in banks' portfolio in Pakistan for last few years. For further details, see the Editorial, Journal of Islamic Business and Management (JIBM) Vol.6 No.1, 2016. Also available at https://ifikr.isra.my/library/pub/9403
} 
TABLE 1

Country Wise Composition of Islamic Banking Investments

\begin{tabular}{lllll}
\hline \hline Country & Muräbahah \% & Ijärah \% & Mushärakah \% & Mudāarabah \% \\
\hline Bahrain & 53 & 20 & 11 & 02 \\
Bangladesh & 45 & 32 & 01 & 04 \\
Egypt & 10 & 00 & 00 & 00 \\
Indonesia & 24 & 12 & 01 & 00 \\
Iran & 00 & 00 & 43 & 04 \\
Jordan & 00 & 71 & 00 & 02 \\
Kenya & 44 & 02 & 55 & 00 \\
Kuwait & 83 & 00 & 00 & 00 \\
Lebanon & 05 & 00 & 00 & 01 \\
Malaysia & 11 & 17 & 03 & 00 \\
Pakistan & 28 & 28 & 03 & 01 \\
Qatar & 65 & 22 & 00 & 02 \\
Saudi Arabia & 16 & 10 & 03 & 00 \\
South Africa & 00 & 00 & 54 & 00 \\
Sudan & 00 & 00 & 41 & 00 \\
Thailand & 00 & 05 & 00 & 00 \\
Tunisia & 30 & 00 & 00 & 00 \\
UAE & 53 & 30 & 04 & 05 \\
UK & 17 & 84 & 00 & 00 \\
Yemen & 38 & 00 & 03 & 14 \\
Average & 30 & 20 & 07 & 02 \\
Author Calculated country wise averages based on Banks in Appendix I \\
\hline \hline
\end{tabular}

Figure 1 provides the country wise average value of deposit returns as a percentage of total deposits for all the banks included in the study. It can be seen that there are very few countries which have deposit returns of more than 10\%. Economies which developed Islamic banking markets like Malaysia, Pakistan and Indonesia are hovering around 5\%; nonetheless, there is an increasing trend of natural log of deposit returns shown in Figure 2. Further, the trade based financing as a share in total financing is found to be negatively correlated with the deposit returns.

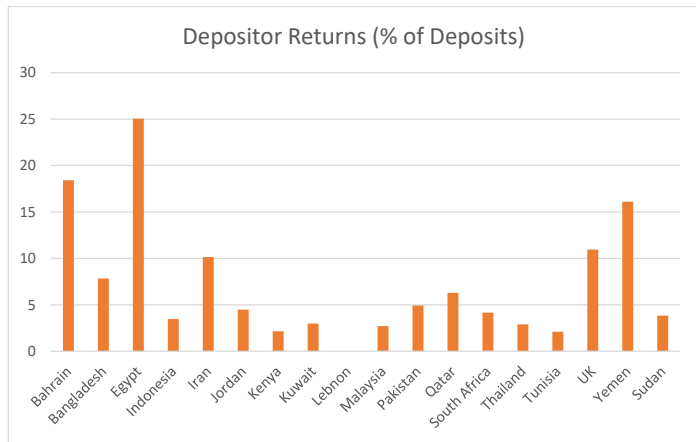

FIGURE 1. Country average of deposit return to total deposits 


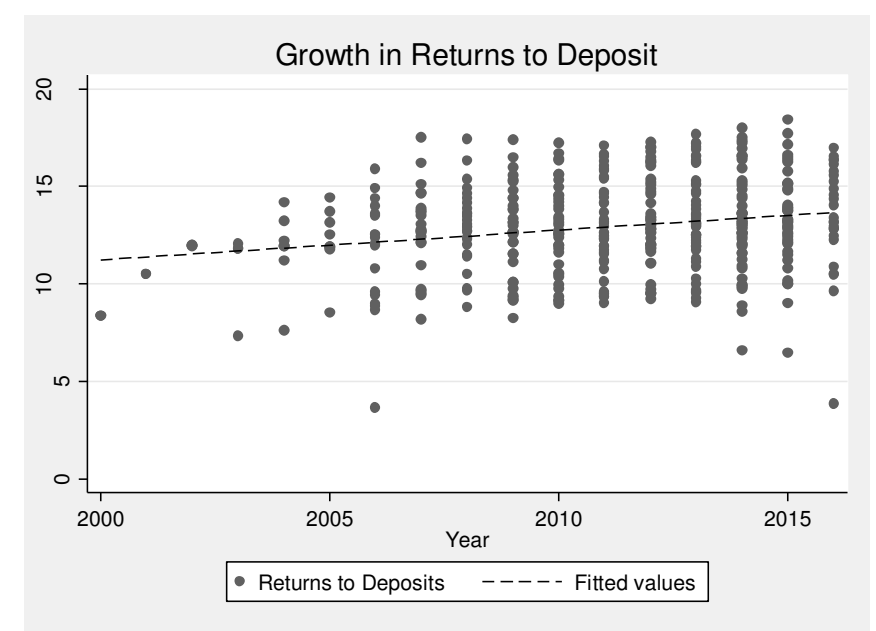

FIGURE 2. Country average of deposit return to total deposits

Figure 3 depicts a dilemma, where only the modes of finance (in bottom two graphs) are positively correlated with the deposit returns while their share in total financing is surprisingly low as indicated in table 1 . This points to a notion that Islamic banks can consider maximization of deposit returns while setting their investment portfolios with higher shares of modes of finance. Though deposit returns are considered as cost to banks and several studies, (Srairi, 2010, Sufian, Kamarudin, Noor, \& Haziaton, 2012; Yudistira, 2004) worked on efficiency of cost minimization, yet none of them considered increasing deposit return as a way to distribute resources in the economy as directed in (Qur'ān, 59:7). Empirical work on the objective of Islamic business also depicted that they overweight social benefit creation over private benefit (Amin \& Yusof, 2003; Yusof \& Amin, 2007).

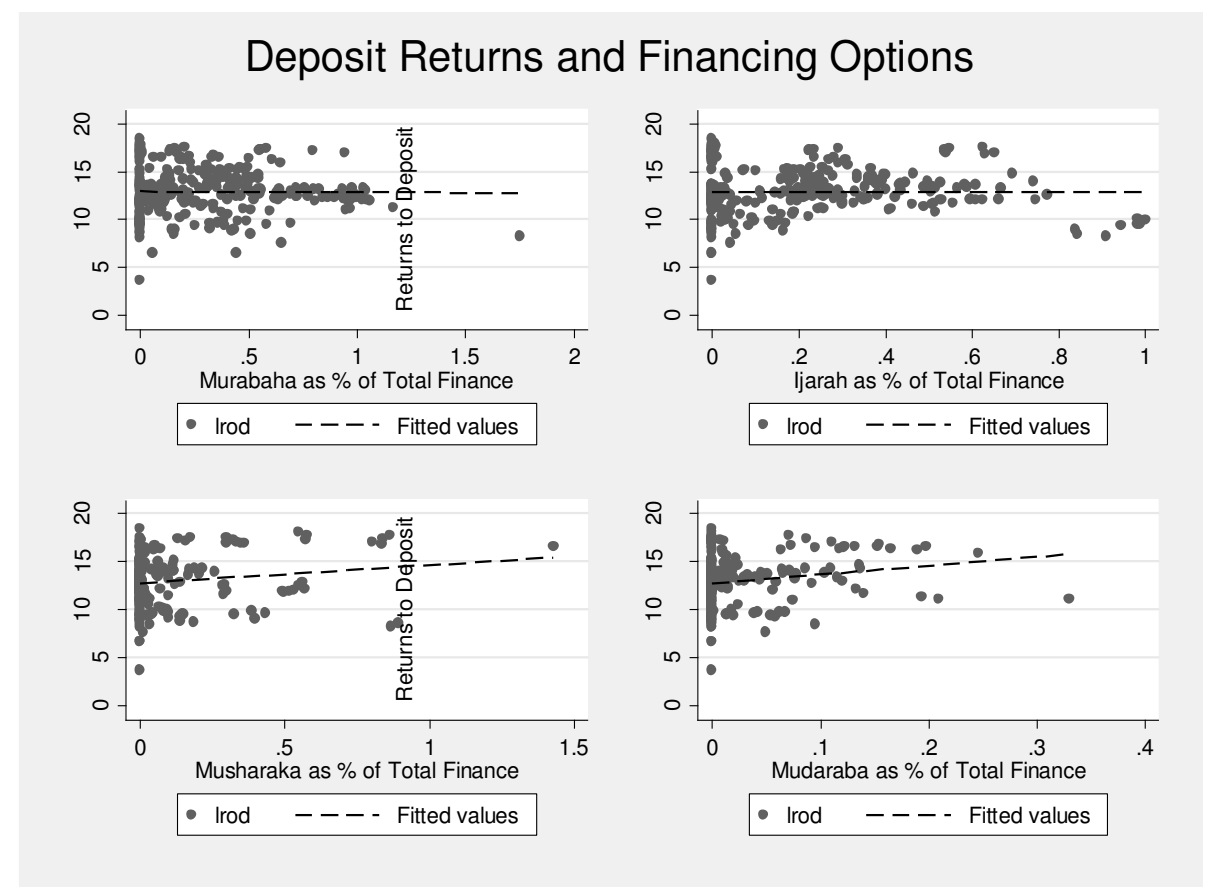

FIGURE 3. Country average of deposit return to total deposits 


\section{ESTIMATION MODEL}

Here Islamic banks have 4 types of investment as inputs at their disposal having different functions and risk/return orientation. Utilization of these inputs will follow the production process to have some expected yield, SFA approach will help in identification how efficient this production process is.

$$
E\left(\text { OUTPUT }_{i t}\right)=f\left(I N P U T_{i t}\right)
$$

Solving for expectations we have

$$
\text { OUTPUT }_{i t}=f\left(\text { INPUTS }_{i t}\right)+\varepsilon_{t}
$$

Since the output is Returns to Deposit (ROD) and inputs are the four proposed investment options represented in terms of Cobb (1928) and Klein (1971) production function specification

$$
R O D_{i t}=f\left(M U S_{i t}, M U D_{i t}, M U R_{i t}, I J A_{i t}\right)+\varepsilon_{i t}
$$

Where ROD is Return on Deposits, MUS is mushärakah financing as percent of total financing, MUD is mudārabah financing as percent of total financing, MUR is murābahah financing as percent of total financing and IJA is ijärah financing as percent of total financing.

Islamic banks have a variable rate of deposit returns, which are sensitive to number of mudāarabah and mushärakah contracts as it partially absorbs the risk (Khan \& Mirakhor, 1987; Sundarajan \& Errico, 2002). Abusharbeh (2016) and Rosley and Zaini (2008) stated that for Islamic banks, non-performing financing (receivables in default) and higher credit risk have negative influence on depositors as they reduce deposit returns. Hamza (2016) contended that the increase in investment deposits in Islamic bank depends on the preferences set by the bank. Any non-utilized funds will negatively affect returns of deposits (Bikker \& Gerritsen, 2017). It has been observed that well-structured equity based financing helps in maximizing deposit returns (Abdul-Rahman Latif, Muda, \& Abdullah, 2014; Diamond, 1984; Muda \& Ismail, 2010). Lastly, banks have to preserve their assets by investing in ventures which have lower risk of loss to avoid depositors' withdrawals (Ahmed, 2002), but consistent low returns in long run will force withdrawal (Ahmed, 2003).

In this output frontier approach, the scalar $\mathrm{K}$ represents the degree of efficiency, $\mathrm{K}=1$ means the production function is $100 \%$ efficient.

$$
R O D_{i t}=f\left(M U S_{i t}, M U D_{i t}, M U R_{i t}, I J A_{i t}\right) * K+\varepsilon_{i t}
$$

Taking natural log of the function we have

$$
R O D_{i t}=f\left(M U S_{i t}, M U D_{i t}, M U R_{i t}, I J A_{i t}\right)+\mu_{i t}+\varepsilon_{i t}
$$

Where $\mu_{i t}=\ln (K)$ 
Now the SFA approach adds a scalar $\mathrm{Z}$ which is +1 for cost minimization function and -1 for output/revenue maximization function.

$$
R O D_{i t}=f\left(M U S_{i t}, M U D_{i t}, M U R_{i t}, I J A_{i t}\right)+Z \mu_{i t}+\varepsilon_{i t}
$$

Using linear log function we have

$$
R O D_{i t}=\alpha+\beta_{1} M U S_{i t}+\beta_{2} M U D_{i t}+\beta_{3} M U R_{i t}+\beta_{4} I J A_{i t}+Z \mu_{i t}+\varepsilon_{i t}
$$

Here we can see that SFA approach splits the distance from the efficient production line into technical inefficiency component and random heteroskedasticity. There are two variants of SFA, first is time varying decay in which the $\mu_{i t}$ component is allowed to change in time and second is time invariant in which $\mu_{i t}$ component is time invariant (Battese \& Coelli, 1992; Kumbhakar \& Lovell, 2000).

SFA reports the variation in technical inefficiency as $\delta_{u}$ and variation in random heteroscedasticity as $\delta_{\varepsilon}$. So technical efficiency can be determined as follows. SFA approach in STATA measures TE using $E(\exp (-\mu) \mid \varepsilon)$.

$$
T E_{i t}=E(\exp (-\mu \mid \varepsilon))=1-\frac{\delta_{\mu i t}}{\delta_{\mu i t} \delta_{\varepsilon i t}}
$$

The average value of TE will identify the efficiency of Islamic banks in converting investment as inputs into a return to deposit as outputs. Using this indicator for a return to deposit efficiency for banks, this study will explore its determinants as second model, using following equation.

$$
\begin{array}{r}
T E_{i t}=\alpha+\beta_{1} M U S_{i t}+\beta_{2} M U D_{i t}+\beta_{3} M U R_{i t}+\beta_{4} I J A_{i t}+\beta_{5} D C P S_{i t}+\beta_{6} I R T_{i t}+\beta_{7} C R_{i t} \\
+\beta_{8} R O B_{i t}+\beta_{9} \text { Trend }+\gamma_{i t}
\end{array}
$$

Here TE is technical efficiency in deposit return maximization, DCPS is domestic credit to private sector as proxy of banking sector development, IRT is market interest rate, CR is total liabilities and total asset ratio as proxy of credit risk, ROB is profit after taxation and Trend is time trend variable.

SBP (2005) report indicated that increase in the banking sector development also increases the intangible benefits of having a bank account. The speculative motive of money demand depicts that increase in the interest rate motivates people to save and channel it into financial system (Mankiw, 2006) leading to growth in deposits. Ergec and Arslan (2013), Ito (2013) and Mushtaq and Siddiqui (2017) showed that increase in the interest rates increases expectation of the people that banks would be earning higher. This forces banks to transfer the higher returns to depositors. While Abduh, Omar, and Duassa (2011) claimed that interest rate and banking profit do not affect deposits of the banks. For the case of credit risk caused by increased deposits, the distributable returns available at the bank will be spread thinly leading to lower returns (The Hindu, 2017; Yadav, 2017). 
The equation 2 would identify which of the proposed investments could lead to increase in efficiency of this output function including also some bank based (i.e., ROB and CR) and economy based indicators (i.e., DCPS, and IRT) of the efficiency.

\section{Theoretical Model Assumptions}

The model which this study has proposed is based on following assumptions:

a) Islamic banks face perfect competition in terms of Islamic finance demand. This ensures that at all times there are many clients to demand mushārakah, muḍarabah, murābaḥah and ijärah financing.

b) Since it is perfect competition, Islamic bank cannot influence any rate of return, hence all type of financing is equally preferable in terms of market returns.

\section{Variables}

Following (Table 2) are the variables with their abbreviations, construction and source, which have been used in model 1 and 2.

TABLE 2

Country Wise Composition of Islamic Banking Investments

\begin{tabular}{|c|c|c|}
\hline Variable (Symbol) & Units and Transformation & Source \\
\hline Returns to Deposit (ROD) & $\begin{array}{l}\text { Local Currency Unit } \\
\text { (natural log) }\end{array}$ & Annual Reports \\
\hline $\begin{array}{l}\text { Mushārakah Financing } \\
\text { (MUS) }\end{array}$ & $\%$ of Total Financing & Annual Reports \\
\hline Muḍārabah Financing (MUD) & $\%$ of Total Financing & Annual Reports \\
\hline Murābaḥah Financing (MUR) & $\%$ of Total Financing & Annual Reports \\
\hline Ijārah Financing (IJA) & $\%$ of Total Financing & Annual Reports \\
\hline $\begin{array}{l}\text { Domestic Credit to Private } \\
\text { Sector (DCPS) }\end{array}$ & $\%$ of GDP & $\begin{array}{l}\text { World Development } \\
\text { Indicators }\end{array}$ \\
\hline $\begin{array}{l}\text { Interest Rate (MMR) Money } \\
\text { market rate }\end{array}$ & $\%$ per annum & $\begin{array}{l}\text { International Finan- } \\
\text { cial Statistics }\end{array}$ \\
\hline Credit Risk (RISK) & Liabilities as a $\%$ of Assets & Annual Reports \\
\hline Net Profit (ROB) & $\begin{array}{l}\text { Local Currency Unit (natu- } \\
\text { ral log) }\end{array}$ & Annual Reports \\
\hline Time trend (Trend) & $\begin{array}{l}\text { No of years from first obser- } \\
\text { vation of the bank }\end{array}$ & Self-Calculated \\
\hline
\end{tabular}

Table 3 shows the descriptive statistics of the variables included in the study, here only for the case of mushārakah and mudārabah financing, all other variables have mean value higher than standard deviation, this shows that mushärakah and mudārabah are over dispersed i.e., its value is not similar across all the banks. While exploring the skewness and kurtosis values they are not near to 0 and 3 respectively, indicating non-normal data. This study has used panel normality test by Alejo, Galvo, Montes-Rojas, and Sosa-Escudero (2015) which has used Jarque and Bera (1987) methodology on cross section (u) and time 
series (e) portion of data. Here it can be seen that other than murābahah financing, ijārah financing and domestic credit to private sector the data is not normal in both accounts, which requires large sample to be estimated (Rosenblatt, 1956) and favors against the use of pooled OLS.

TABLE 3

Descriptive Statistics

\begin{tabular}{llllllllll}
\hline \hline & ROD & MUS & MUD & MUR & IJA & DCPS & MMR & RISK & ROB \\
\hline Mean & 12.93 & 0.07 & 0.02 & 0.30 & 0.20 & 3.91 & 5.01 & 0.76 & 12.40 \\
Std. Dev. & 2.42 & 0.34 & 0.23 & 0.17 & 0.04 & 0.70 & 4.00 & 0.26 & 2.24 \\
Skewness & -0.26 & 3.73 & 3.10 & 2.31 & 1.75 & -0.67 & 1.20 & -1.56 & -0.23 \\
Kurtosis & 3.20 & 19.92 & 14.71 & 14.43 & 7.85 & 3.56 & 3.95 & 4.15 & 2.37 \\
Normality e & 8.88 & 3.63 & 10.84 & 3.51 & 3.63 & 2.06 & 39.37 & 17.75 & 25.88 \\
& $(0.01)$ & $(0.16)$ & $(0.00)$ & $(0.17)$ & $(0.16)$ & $(0.36)$ & $(0.00)$ & $(0.00)$ & $(0.00)$ \\
Normality u u & 2.91 & 22.6 & 6.66 & 9.75 & 9.68 & 5.35 & 10.03 & 12.51 & 7.17 \\
& $(0.23)$ & $(0.00)$ & $(0.04)$ & $(0.01)$ & $(0.01)$ & $(0.07)$ & $(0.01)$ & $(0.00)$ & $(0.03)$ \\
Obs. & 330 & 330 & 330 & 330 & 330 & 330 & 330 & 330 & 330 \\
\hline \hline
\end{tabular}

\section{RESULTS}

Stochastic frontier model estimates are presented in Table 4. Significant Wald test indicates that the proposed inputs are significantly affecting the returns to deposit, while the insignificant value of ETA indicates that the efficiency of this input-output function is time invariant.

The estimates show that if Islamic bank increases $1 \%$ of the trade based investment (ijärah (IJA) and muräbahah (MUR)), it will lead to decrease in the returns to deposit by $1.65 \%$ and $1.04 \%$ respectively. The coefficients are bigger than 1 in magnitude indicating that the decrease in return to deposit is higher than increase in investment share, so though banks are moving towards less risky investments, but deposits will experience the decline in their shares. If Islamic bank increases $1 \%$ in variable return based investment (mushärakah (MUS) and muda arabah (MUD)), it will lead to increase in returns to deposit by $0.59 \%$ and $2.26 \%$ respectively, where mudärabah financing shows potential to increase deposit return twice the amount of increase in muda arabah investment, the results are similar to the case of banking profit (Arshed et al., 2017). Surprisingly this mode of investment is insignificant; it shows that the current share of this mode of finance is so low that any increase in such investment is being offset by the increase in the risk. 
TABLE 4

Stochastic Frontier Model

\begin{tabular}{ll}
\hline \multicolumn{2}{c}{ Panel Stochastic Frontier Model: Dependent variable $\mathrm{ROD}_{i t}$} \\
\hline Independent Variable & Coefficient $[t$ value $]$ \\
\hline MUS $_{\text {it }}$ & $0.59[1.17]$ \\
MUD $_{\text {it }}$ & $2.26[1.11]$ \\
MUR $_{\text {it }}$ & $-1.04[-.3 .78]^{*}$ \\
IJA $_{\text {it }}$ & $-1.65[-3.41]^{*}$ \\
Intercept & $18.51[28.4]^{*}$ \\
Sigma-u Square & $6.16[3.78]^{*}$ \\
Sigma-v Square & $0.76[11.6]^{*}$ \\
ETA & $0.005[0.59]$ \\
Sample & 330 \\
Panels (Banks) & 46 \\
Average years per bank & 7 \\
Wald & $27.19(0.00)^{*}$ \\
TE & 0.30 \\
\hline \hline
\end{tabular}

$p$ values in parenthesis $*$ Significant at $1 \%$

Table 4 also provides the estimates of the square of technical inefficiency variation which is 6.16 and square of random heteroscedasticity which is 0.76 . Using the formula provided for Technical Efficiency (TE), this model proposes that all the included banks jointly are approximately $26 \%^{2}$ efficient in converting investment input to deposit return output, indicating that there is no sincere consideration of optimizing the investments to maximize the deposit returns. This efficiency value varies significantly across the countries. Figure 4 shows the country wise dispersion of efficiency values. Here Bahrain, Bangladesh, Iran and Kenya are prominent countries where the efficiency rate is $52 \%, 79 \%, 58 \%$ and $48 \%$ respectively, while there are few others which are above sample average, represented by the horizontal line. Surprisingly, big markets of Islamic banks like Indonesia and Pakistan are under the average and Malaysia is just exceeding it.

${ }^{2} T E_{i t}=1-\frac{\delta_{\mu i t}}{\delta_{\mu i t}+\delta_{\varepsilon i t}}=1-\frac{\sqrt{6.16}}{\sqrt{6.16}+\sqrt{0.76}}=0.26$ 


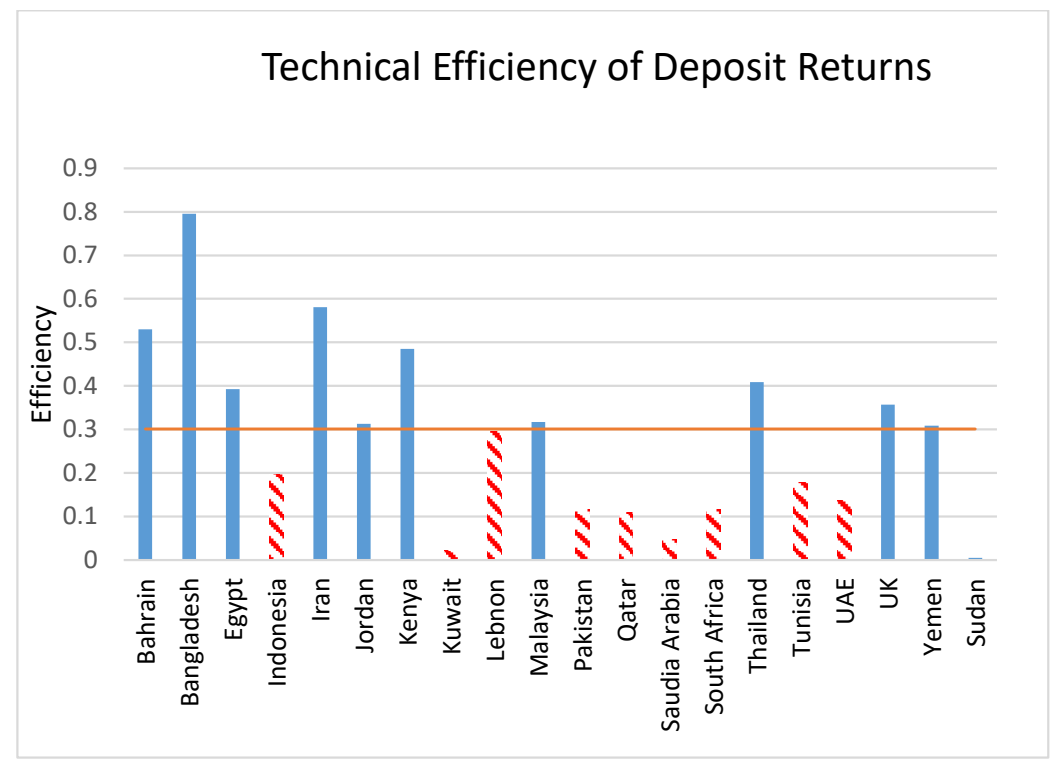

FIGURE 4. Country wise efficiency of deposit returns estimates

Figure 5 illustrates the comparison of trade based (IJA + MUR) and investment based (MUS + MUD) portfolio with the efficiency of deposit returns. It can be seen here that the circles which are representing the trade based investments are scattered everywhere indicating that generally, they have a small association with the efficiency of deposit returns also confirmed by the horizontal linear fit line. While the triangles represent the investment based returns, though they are scattered near to zero still they are indicating a positive association with deposit returns, and is confirmed using the positive sloped linear fit line.

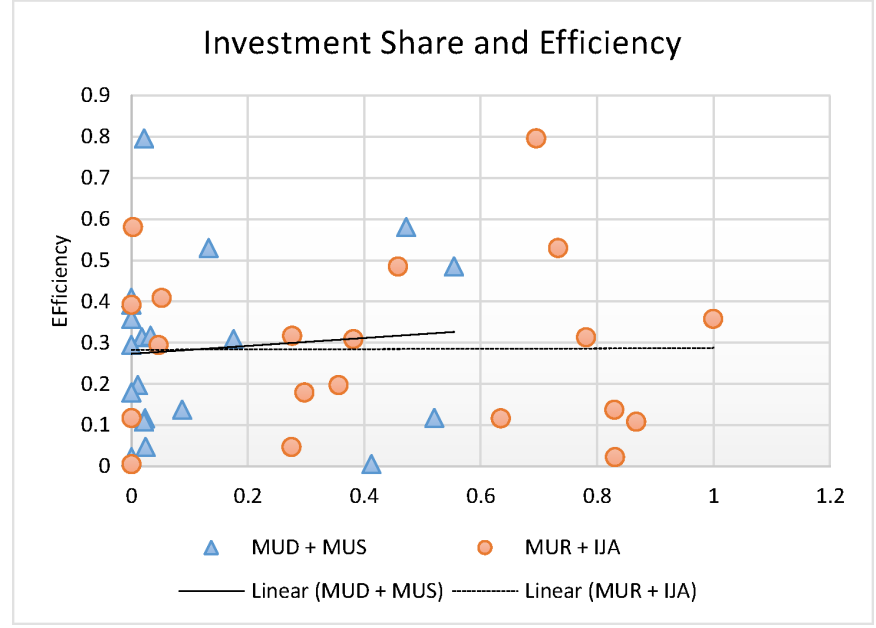

FIGURE 5. Investment type and efficiency of deposit returns

Determinants of efficiency are estimated by using equation 2. This equation is tested for any nonlinear effect of an independent variable using the added variable plot. Figure 6 plots the linear coefficients of added variables on scatterplot. It can be seen that the mudarabah financing (second graph in first column) seems not to represent the linear coefficient line. This necessitates the use of a squared form of mudārabah financing variable in the estimates reported in Table 3. 


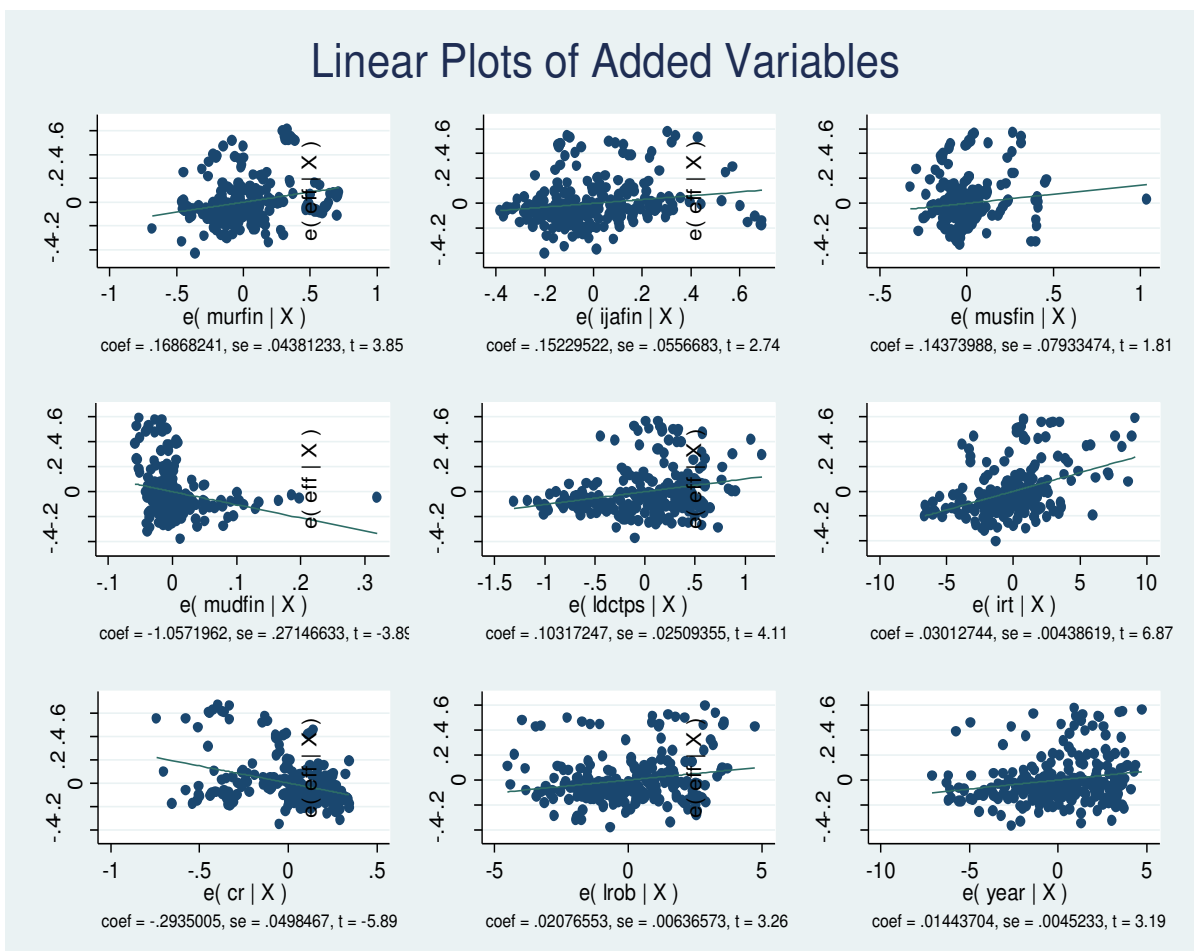

FIGURE 6. Added variable plot

Table 5 reports the results of model 2 related to the determinants of the efficiency of deposit returns. The F-test indicates that the proposed variables are significant in explaining the efficiency of deposit returns.

Results in Table 3, include the investment options which would help in ranking the investment options in terms of their potential to increase efficiency. This model is estimated using time fixed effect model based on 48 panels. The Hausman test indicates that fixed effect estimates are appropriate. In this model the negative value of intercept depicts that if all included variables become zero, deposit return efficiency will fall by $32.43 \%$ on average. Further, the included variables are explaining $38 \%$ changes in the dependent variable.

It can be seen that all four investment options have a positive effect on efficiency with mushārakah financing (MUS) having the highest potential. Surprisingly for mudarabah financing (MUD), ${ }^{3}$ the U-shape relationship indicates that there is a high potential for muda arabah financing. It indicates that mudärabah financing will have a negative effect initially but if it is increased up and beyond $17 \%$ of total financing, it will have a positive impact. Currently, muda arabah financing is on average is $2 \%$ in all full-fledged Islamic banks based on the average of full-fledged Islamic banks in sample (shown in Table 1).

$3_{E F F}=-2.36 M U D+6.91 M U D^{2}$

$\delta E E F / \delta M U D=-2.36+13.82 M U D$

$M U D=0.02$

So mean linearized coefficient of Mudaraba financing is -2.08 , it means at mean value of Mudaraba financing its effect on efficiency is negative.

Minimum Mudaraba financing required for positive effect is

$\delta E E F / \delta M U D=-2.36+13.82 M U D=0$

$M U D=0.17 \%$ 
The remaining independent variables in Table 5 are the possible determinants of efficiency. If the Development of Banking Sector (DCPS) is increased by $1 \%$ such that the private sector starts to use $1 \%$ more of credit provided by the banking system, then the efficiency of Islamic banks will increase by $0.09 \%$ on average. Thus the increase in demand for funds will increase the price of funds which is returns of investment for the banks (SBP, 2005). Similarly, if the average profitability of investments indicated by Market Interest Rate (MMR) increases by $1 \%$ then Islamic banking efficiency of generating deposit returns will increase by $0.03 \%$ which is confirmed by loanable fund market theory (Ergec \& Arslan, 2013; Ito, 2013; Mankiw, 2006; Mushtaq \& Siddique, 2017). Also, if credit risk (RISK) associated with the bank increases by $1 \%$, then the efficiency will decrease by $0.24 \%$. This shows that if there are too many liabilities (like bills payable and borrowed funds) then bank's cost of doing business will increase which will reduce the deposit returns (Yadav, 2017). If the profit of the Islamic banks (ROB) increases by $1 \%$, it will increase the efficiency by $0.01 \%$ indicating that if banks earn higher with same investment portfolio then it will improve the deposit return production function. Lastly, the trend variable is incorporating the effect of an increase in knowledge, age and experience of Islamic banks, here each year the efficiency is increasing by $0.02 \%$ because of development in banking practices and better financial products.

TABLE 5

Determinants of Efficiency

\begin{tabular}{ll}
\hline \hline \multicolumn{2}{c}{ Determinants of Deposit Return Efficiency } \\
\hline Variables & Fixed Effect Estimates \\
\hline MUS $_{\text {it }}$ & Coefficients $[t$ value] \\
MUD $_{\text {it }}$ & $0.19[2.44]^{*}$ \\
MUD $_{\text {it }}^{2}$ & $-2.36[-3.98]^{*}$ \\
MUR $_{\text {it }}$ & $6.91[2.49]^{*}$ \\
IJA $_{\text {it }}$ & $0.18[4.34]^{*}$ \\
DCPS $_{\text {it }}$ & $0.15[3.01]^{*}$ \\
MMR $_{\text {it }}$ & $0.09[3.97]^{*}$ \\
RISK $_{\text {it }}$ & $0.03[7.24]^{*}$ \\
ROB $_{\text {it }}$ & $-0.24[-5.62]^{*}$ \\
Trend & it \\
Intercept $_{F}$ & $0.01[2.16]^{*}$ \\
$F$ test & $0.02[3.94]^{*}$ \\
Sample & $-32.43[3.97]^{*}$ \\
Panels (Banks) & $14.52(0.00)^{*}$ \\
$R$-squared & 296 \\
Adjusted R-squared & 46 \\
Hausman Test & 0.38 \\
\hline \hline$p$ values in parenthesis * Significant at $1 \%$ &
\end{tabular}


Figure 7 shows the share of each independent variable in a total change in the dependent variable caused by the model (which is explained by $R^{2}$ ) proposed by Hedges (1981). Since $R^{2}$ is 0.34 so all independent variables jointly explain 34\% change in the efficiency of deposit returns. Here we can see that change in interest rate, and credit risk shows high share in explaining efficiency of deposit returns. While comparing the investment options, mudārabah financing has the highest share.

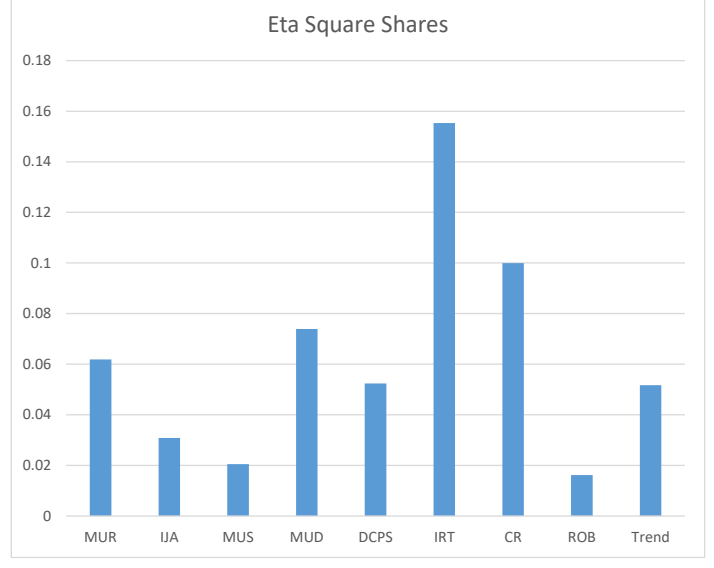

FIGURE 7. Eta square shares of independent variables

\section{CONCLUSION \& POLICY IMPLICATIONS}

Globally Islamic banks are in competition with the conventional banks, thus for attracting depositors, Islamic banks have to offer higher deposit returns. This study builds on the idea that the depositors are the provider of funds to the bank, which is used in various types of investments that yield a profit to the bank and return to the depositor. So in order to boost the deposit returns as a target to attract funds, Islamic banks have to optimize the investments.

But there is a weak substitutability between the trade based financing which has low return and low risk, and the investment based funding which has high return and high risk. Because of this tradeoff, this study first investigated the degree of efficiency Islamic banks have achieved in generating return to deposit from investment portfolio. Secondly, it compared which of the financing/investments (out of mushārakah, mudārabah, ijārah, and murābahah) has potential to increase the efficiency, if increased. Lastly, this study tested some indicators of efficiency which are based on market conditions.

This study has used the SFA approach on all 53 known full-fledged Islamic banks for data between 2001 2015, which traced the production possibility frontier based on the data of inputs which are investment options and output which is deposit returns. Here simple Cobb (1928) production function was used. SFA approach then compared individual observation with the benchmark and distributed the difference into two portions. First was the technical inefficiency and second was random heteroskedasticity. Technical inefficiency is described as a portion which is because of differences between the banks (Greene, 2005a; 2005b) in the study while the random heteroskedasticity is the random variation around the benchmark whose average is zero. 
The estimates of SFA indicated that increase in ijārah and murābahah financing would lead to decrease in the deposit returns, while the impact of mushārakah and mudārabah financing on deposit return appeared insignificant. On the basis of results it is concluded that Islamic banks are about $30 \%$ efficient in converting the investment inputs into deposit return output. The $70 \%$ inefficiency might account for the cost of providing banking services, differences in risk mitigating techniques and competition with conventional banks. The low efficiency indicates that as per cash flow treatment, returns to depositors are actually cost to the bank and according to theory of firm, a bank has to minimize this cost. On the other side, as per conventional banking increase in this cost might lead to customer patronization, similarly since Islamic banks treat depositors as partners so it is expected that it might try to optimize the deposit returns for better customer relations. Second possible reason of low efficiency is new predicament of maturity mismatch between deposit amount and investment opportunities, which is because of scarcity of short term money market instruments in Islamic banks (similar issue raised by, Islam \& Amir, 2016).

While analyzing investment options in terms of their potential to increase the efficiency, the results show that all investment options if increased will lead to increase in the efficiency of Islamic banks. While using the eta-square chart and linearized coefficient of muda rabah financing, it is evident that increasing mudārabah financing offers the highest potential to increase efficiency. Indicators like market interest rate, banking sector development and banking profits boost the efficiency while increase in credit risk will lead to deterioration in efficiency.

This study reveals that Islamic banks, if in competition with the conventional banks, should focus on the welfare perspective and try to increase the deposit returns. This can be done by reducing dependency on the trade based investments and focusing on the financing based investments, which are the true essence of Islamic banking. Central banks, product developers and Sharī'ah advisors should restructure the partnership based modes to make them facilitative for Islamic banks. Islamic banking financing returns can be increased by the efforts of the government, central bank and the banking industry in exploring profitable avenues for investment. Islamic banks can work on reducing the cost of providing services with the help of using online banking to reduce liabilities and thus credit risk. Lastly government can target the development of banking sector by acquiring their services in financing national projects. All of these policy implications will eventually increase the efficiency of the returns production process, which will enable small income depositors to tap on to higher returns. While this study has ignored the distribution of the depositors in terms of their deposit size, it proposes to explore distribution of depositors to see if banking investments has improved the distribution to a higher income level.

\section{REFERENCES}

Abduh, M., Omar, M. A., \& Duasa, J. (2011). The impact of crisis and macroeconomic variables towards Islamic banking deposits. American Journal of Applied Sciences, 8(12), 1413-1418. doi: https://doi.org/10.3844/ajassp.2011.1378.1383

Abdul-Rahman, A., Latif, R. A., Muda, R., \& Abdullah, M. A. (2014). Failure and potential 
of profit-loss sharing contracts: A perspective of New Institutional, Economic (NIE) Theory. Pacific-Basin Finance Journal, 28, 136-151.

doi: https://doi.org/10.1016/j.pacfin.2014.01.004

Abusharbeh, M. T. (2016). Analysis the effect of Islamic banks performance on depositor's fund: Evidence from Indonesia. International Journal of Economics and Finance, 8(10), 40-47. doi: https://doi.org/10.5539/ijef.v8n10p40

Aggarwal, R. K., \& Yousef, T. (2000). Islamic banks and investment financing. Journal of Money, Credit and Banking, 32(1), 93-120. doi: https://doi.org/10.2307/2601094

Ahmed, H. (2002). A microeconomic model of an Islamic bank (Working paper no. 54). Jeddah, Saudi Arabia: The Islamic Research and Teaching Institute (IRTI).

Ahmed, H. (2003). Withdrawal risk in Islamic banks, market discipline and bank stability. Paper presented at the International Conference on Islamic Banking: Risk Management, Regulation and Supervision, Jakarta, Indonesia.

Ahmed, H. (2011). Product development in Islamic banks. Edinburgh, UK: Edinburgh University Press.

Alejo, J., Galvo, A., Montes-Rojas, G., \& Sosa-Escudero, W. (2015). Test for normality in linear panel-data models. The Stata Journal, 15(3), 822-832.

doi: https://doi.org/10.1177/1536867X1501500314

Amin, R. M., \& Yusof, S. A. (2003). Allocative efficiency of profit maximization: An Islamic perspective. Review of Islamic Economics, 13, 5-22.

Arshed, N., Riaz, S., \& Khan, T. M. (2017). Financial disintermediation and profitability of global Islamic banks. European Journal of Islamic Finance, 7, 1-12.

Ayub, M. (2009). Understanding Islamic finance (Vol. 462). New York, NY: John Wiley \& Sons.

Battese, G. E., \& Coelli, T. J. (1992). Frontier production functions, technical efficiency and panel data: With application to paddy farmers in India. Journal of Productivity Analysis, 3(1-2), 153-169. doi: https://doi.org/10.1007/BF00158774

Bhattacharyya, A., Lovell, C. K., \& Sahay, P. (1997). The impact of liberalization on the productive efficiency of Indian commercial banks. European Journal of operational research, 98(2), 332-345. doi: https://doi.org/10.1016/S0377-2217(96)00351-7

Bikker, J. A., \& Gerritsen, D. F. (2018). Determinants of interest rates on time deposits and savings accounts: Macro factors, bank risk, and account features. International Review of Finance, 18(2), 169-216. doi: https://doi.org/10.1111/irfi.12143

Cobb, C. W. (1928). Douglas PH: Theory of production. American Economic Review, Supplement, 18(1), 139-165.

Diamond, D. W. (1984). Financial intermediation and delegated monitoring. The Review of Economic Studies, 51(3), 393-414. doi: https://doi.org/10.2307/2297430

Dusuki, A. W., \& Abozaid, A. (2007). A critical appraisal on the challenges of realizing maqasid Al-Shariaah in Islamic banking and finance. International Journal of Economics, Management and Accounting, 15(2), 143-165.

Ergeç, E. H., \& Arslan, B. G. (2013). Impact of interest rates on Islamic and conventional banks: The case of Turkey. Applied Economics, 45(17), 2381-2388.

doi: https://doi.org/10.1080/00036846.2012.665598 
Garcia, M. T. M., \& Guerreiro, J. P. S. M. (2016). Internal and external determinants of banks' profitability: The Portuguese case. Journal of Economic Studies, 43(1), 90-107. doi: https://doi.org/10.1108/JES-09-2014-0166

Greene, W. (2005a). Fixed and random effects in stochastic frontier models. Journal of productivity analysis, 23(1), 7-32. doi: https://doi.org/10.1007/s11123-004-8545-1

Greene, W. (2005b). Reconsidering heterogeneity in panel data estimators of the stochastic frontier model. Journal of Econometrics, 126(2), 269-303.

doi: https://doi.org/10.1016/j.jeconom.2004.05.003

Hadi, F., \& Hani, A. (2015). Specifics of Tawarruq financing models in Islamic banking. Review of Applied Socio-Economic Research, 123-139.

Hamza, H. (2016). Does investment deposit return in Islamic banks reflect PLS principle? Borsa Istanbul Review, 16(1), 32-42. doi: https://doi.org/10.1016/j.bir.2015.12.001

Haron, S., Azmi, W. N. W., \& Shafie, S. (2006). Deposit determinants of commercial banks in Malaysia. Finance India, 20(2), 531-551.

Hassan, Z. (2014). Islamic banking and finance, An integrative approach. Oxford, UK: Oxford Press.

Hedges, L. V. (1981). Distribution theory for Glass's estimator of effect size and related estimators. Journal of Educational Statistics, 6(2), 107-128.

Hussain, M., Shahmoradi, A., \& Turk, R. (2016). An overview of Islamic finance. Journal of International Commerce, Economics and Policy, 7(1), 1-28.

Iqbal, Z., \& Mirakhor, A. (2011). An introduction to Islamic finance: Theory and practice (Vol. 687). Hobkon, NJ: John Wiley \& Sons. doi: https://doi.org/10.1002/9781118390474

Islam, A., \& Amir, S. (2016). Liquidity problems in Islamic banks; Reasons, impacts and solutions. COMSATS Journal of Islamic Finance, 1, 1-9.

doi: https://doi.org/10.26652/cjif.120161

Ito, T. (2013). Islamic rates of return and conventional interest rates in the Malaysian deposit market. International Journal of Islamic and Middle Eastern Finance and Management, 6(4), 290-303. doi: https://doi.org/10.1108/IMEFM-11-2012-0113

Jarque, C. M., \& Bera, A. K. (1987). A test for normality of observations and regression residuals. International Statistical Review/Revue Internationale de Statistique, 55(2), 163-172.

Kasri, R., \& Kassim, S. H. (2009). Empirical determinants of saving in the Islamic banks: Evidence from Indonesia. Journal of King Abdulaziz University: Islamic Economics, 22(2), 181-201. doi: https://doi.org/10.4197/islec.22-2.7

Khan, I. (2007). Islamic finance: Relevance and growth in the modern financial age. Paper presented at the Islamic Finance Seminar, Harvard Islamic Finance Project, London School of Economics, London, UK.

Khan, M., \& Mirakhor, A. (1989). The financial system and monetary policy in an literature. Journal of King Abdulaziz University: Islamic Economics, 1, 39-57.

Klein, M. A. (1971). A theory of the banking firm. Journal of Money, Credit and Banking, 3(2), 205-218. doi: https://doi.org/10.2307/1991279 
Kumbhakar, S. C., \& Lovell, C. K. (2003). Stochastic frontier analysis. Cambridge, UK: Cambridge University Press.

Maali, B., Casson, P., \& Napier, C. (2006). Social reporting by Islamic banks. Abacus, 42(2), 266-289. doi: https://doi.org/10.1111/j.1467-6281.2006.00200.x

Mankiw, N. G. (2006). Principles of macroeconomics. Mason, OH: Cengage Learning.

Mokhtar, H. S. A., Abdullah, N., \& Al-Habshi, S. M. (2006). Efficiency of Islamic banking in Malaysia: A stochastic frontier approach. Journal of Economic Cooperation, 27(2), 37-70.

Muda, R., \& Ismail, A. G. (2010). Profit-loss sharing and value creation in Islamic banks. Journal of Business and Policy Research, 5(2), 262-281.

Mushtaq, S., \& Siddiqui, D. A. (2017). Effect of interest rate on bank deposits: Evidences from Islamic and non-Islamic economies. Future Business Journal, 3(1), 1-8. doi: https://doi.org/10.1016/j.fbj.2017.01.002

Rachmawati, E., \& Syamsulhakim, E. (2004). Factors affecting mudaraba deposits in Indonesia. Paper presented at the Third International Islamic Banking and Finance Conference, Petaling Jaya, Malaysia.

Rosenblatt, M. (1956). A central limit theorem and a strong mixing condition. Proceedings of the National Academy of Sciences of the United States of America, 42(1), 43-47. doi: https://doi.org/10.1073/pnas.42.1.43

Rosly, A. S., \& Zaini, M. A. M. (2008). Risk-return analysis of Islamic banks' investment deposits and shareholders' fund. Managerial Finance, 34(10), 695-707. doi: https://doi.org/10.1108/03074350810891010

Sadiq, R., Arshed, N., \& Ahmad, H. K. (2017). Determinants of cost efficiency of Islamic banks of Pakistan. The Journal of Muamalat and Islamic Finance Research, 14(2), 111-128. doi: https://doi.org/10.12816/0045782

SBP. (2005). Financial sector assessment. Karachi, Pakistan: State Bank of Pakistan.

Srairi, S. A. (2010). Cost and profit efficiency of conventional and Islamic banks in GCC countries. Journal of Productivity Analysis, 34(1), 45-62.

doi: https://doi.org/10.1007/s11123-009-0161-7

Sufian, F., \& Noor, M. A. N. M. (2009). The determinants of Islamic banks' efficiency changes: Empirical evidence from the MENA and Asian banking sectors. International Journal of Islamic and Middle Eastern Finance and Management, 2(2), 120-138. doi: https://doi.org/10.1108/17538390910965149

Sufian, F., Kamarudin, F., Noor, M., \& Haziaton, N. H. (2012). Determinants of revenue efficiency in the Malaysian Islamic banking sector. Journal of King Abdulaziz University Islamic Economics, 25(2), 195-224.

Sundarajan, V., \& Errico, L. (2002). Islamic financial institutions and products in the global financial system: Key issues in risk management and challenges ahead (Working paper no. WP/02/192). International Monetary Fund, Washington, DC, WA.

The Hindu. (2017). Excess liquidity prompts banks to cut deposit rates. Retrieved from https://bit.ly/2Lbq7PW

Usmani, T. (2000). An Introduction to Islamic finance. Karachi, Pakistan: Idara Al Maarif. 
Yadav, R. (2017). Banks cut deposit rates again. Here's how you can still earn higher returns on your investments. Retrieved from https://bit.ly/2PrEAuv

Yan, G. (2005). Determinants of the efficiency of China's commercial banks: Theoretical explore and empirical test. Journal of Finance, 2, 3-48.

Yudistira, D. (2004). Efficiency in Islamic banking: An empirical analysis of eighteen banks. Islamic Economic Studies, 12(1), 1-19.

Yusof, S., \& Amin, R. M. (2007). A survey on the objective of the firm and models of producer behavior in the Islamic framework. Journal of King Abdulaziz University: Islamic Economics, 20(2), 3-16. doi: https://doi.org/10.4197/islec.20-2.1 
Appendix

\begin{tabular}{llll}
\hline \hline Bank & Country & Bank & Country \\
\hline \hline Meezan Bank & Pakistan & Dubai Islamic Bank & UAE \\
Dubai Islamic Bank & Pakistan & Noor Bank & UAE \\
Burj Bank & Pakistan & Sharjah Islamic Bank & UAE \\
Bank Islami & Pakistan & Ajman Bank & UAE \\
Al Baraka Bank & Pakistan & Alhilal Bank & UAE \\
Bank Islam Malaysia Berhad & Malaysia & Bahrain Islamic Bank & Bahrain \\
Bank Muamalat Malaysia Berhad & Malaysia & Al Baraka Bank & Bahrain \\
Affin Islamic Bank & Malaysia & Citi Islamic Bank & Bahrain \\
Alliance Islamic Bank & Malaysia & Al Baraka Bank & Lebnon \\
Asian Finance Bank & Malaysia & Bank Muamalat & Indonesia \\
Cimb Islamic Bank & Malaysia & MayBank Syriah & Indonesia \\
Hong Leong Islamic Bank & Malaysia & Jordan Islamic Bank & Jordan \\
Public Islamic Bank & Malaysia & Islamic International Arab Bank & Jordan \\
Al Rajhi Bank & Malaysia & Gulf African Bank & Kenya \\
Bank Rakyat & Malaysia & Abu Dhabi Bank & Egypt \\
OCBC Al Amin Bank Berhad & Malaysia & Al Baraka Bank & South Africa \\
Koperasi Bank Persatuan & Malaysia & Tadhamon Islamic Bank & Yemen \\
Qatar International Islamic Bank & Qatar & Al Baraka Bank & Thailand \\
Qatar Islamic Bank & Qatar & Al Baraka bank & Sudan \\
Bank Albilad & Saudi Arabia & Al Rayan Islamic Bank & UK \\
Al Rajhi Bank & Saudi Arabia & Islamic Bank of Bangladesh & Bangladesh \\
Alinma bank & Saudi Arabia & Shahjalal Islamic Bank & Bangladesh \\
Bank of Pasargad & Iran & EXIM bank & Bangladesh \\
Bank Maskan & Iran & Al Arafa Islamic Bank & Bangladesh \\
Bank Tejarat & Iran & Kuwait Finance House & Kuwait \\
Abi Dhabi Bank & UAE & & \\
\hline \hline & & & \\
\hline
\end{tabular}

